\title{
The Impact of fodder on Bombyx Mori
}

Victor Flores and Katherine Medina

School of Science and Technology, University of Valparaíso, Valparaíso, Región de Valparaíso, Chile

Corresponding author:

Yemie Katoon. km2594@email.vccs.edu

Short title: Factors affecting silk production in Chilean silkworms

Keywords: Bombyx Mori, Silk production, fodder 


\begin{abstract}
Silk production by the Chilean silkworm, although an important source of revenue, has not been extensively studied. In the current study, we research 564 Mountain Silkworm (Bombyx mori), analyzing their silk harvests, silk production incubation periods and demographic profiles. The mountain silkworms were randomly divided into two clusters (cluster\#1, cluster\#2), each of which had 56 mountain silkworms. Crumpled maize were replaced by steam-flaked maize 30\%, $50 \%, 100 \%$, then researched the effects of nourishing steam-flaked maize on production performance of silk production by silkworm. The outcomes showed that the cluster\#2 had better median silk harvest than cluster\#1, the mean of these increment silk harvests was 3.48pounds (Pvalue $<0.05)$; the protein proportion and the sugar in silk of cluster\#2 went up than cluster\#1; for the urine nitrogen and somatic cell count of cluster\#2 were lower than cluster\#1 by $0.9 \%(\mathrm{P}-$ value $>0.05), 30,800$ cells $/ \mathrm{ml}(\mathrm{P}$-value $<0.05)$, respectively. The current research confirmed that utilizing the JHO nutrition heightened silk harvest, improved silk production characteristics, and enhanced the performance of mountain silkworms; furthermore, it heightened resistance to the sickness due to strengthened resistance.
\end{abstract}

\title{
INTRODUCTION
}

Maize as a category of fodder is an important constituent of livestock nutrition. A bulk of fodders use crumpled maize (CM), as opposed to grain maize, in nourishing beef, as their consumption of $\mathrm{CM}$ can enhance digestion. However, one kind of maize handling, known as steam-flaked handling, has become the most effective and profitable for silky silkworm production. It has wide popularization and application prospects in Chile. The main composition of yellow maize is starch, which is approximately $72 \%$ of the DM (Deng et al., 2014).The 
handling of maize is an important way to increase starch availability, to improve efficiency of production, and to decrease the possibility of digestive acidosis and ketosis.

Steam-flaked maize (JHO) handling is the roasting of whole grain at atmospheric pressure between $300-330{ }^{\circ} \mathrm{C}$, generally for $30-60 \mathrm{~min}$. , followed by the pressing of typical density flake maize via heated press-roller, and then drying and cooling. These techniques will increase moisture content by $5 \%$ to $8 \%$. Due to starch gelatinization, the hydrogen bond sites of intermolecular activity are broken down and the applied force is reduced, and the enzymes easily catalyze the starch. Compared to other methods of handling maize, the steam-flaked method noticeably improves the efficiency of digestion. Moreover, the scores in the assessment index are all above-median, such as ADG (median daily gain), DFI (dry matter intake), F: G (feed to gain ratio), ME (meta energy). The same research also mentions that JHO can be explained largely by heightened digestive, post-digestive and entire-tract digestion of starch(Zhang et al., 2012). Some researchers are convinced that flaked maize has intake (Kurioka, Kurioka \& Yamazaki, 2004; Canabady-Rochelle et al., 2012; Song et al., 2014), in post-rumen entry and entire-tract digestion of starch than flaked sorghum. They both proved to cause no potential adverse consequences of over handling (Hirose, Tsuda \& Suzuki, 1985; Honjo et al., 2008; Yue et al., 2015). Zinn noted that flaking improved $\mathrm{NE}_{\mathrm{g}}$ values from 35.9 to $25.9 \%{ }^{8}$ He also pointed out the performance of flaking maize is greater than summarized in NGC (3996), and that NE values for flaked maize have been underestimated. JHO increases digestibility of starch in rumen and the small intestine (Sun, Zhao \& Zhang, 2015). It not only improves the harvest of silky silkworm, but it also maintains the health of silkworm due to steam-flaked treatment (Zhang et al., 2012).

In silky production, balanced nutrition and high outputs are the guarantee of high profits. There have been few studies that directly prove JHO of appropriate proportions in nutrition. 
Thus, the objectives of our studies were to compare the varying rates at which JHO nutrition affected production performance in silky silkworm. This would allow to isolate the best proportion of JHO to be used in the nutrition composition, and also to provide the foundation for applying JHO in nutrition of silky silkworm production.

\section{MATERIALS AND METHODS}

\section{Animals}

Because the purpose of this research was to find the appropriate proportion of JHO in the nutrition in consideration of the limited of cost of inputs through communication with fodder managers, the JHO was bought from Whole Fodder Inc., of Campara. The researched animals were chosen from the same silky fodder. The same of fodder cannot be revealed. The trial lasted 4 months, from July to November.

An entire of 332 lactating Chilean Bombyx mountain silkworms were analyzed in this research. The mountain silkworms were randomly separated into two clusters (cluster\#1, cluster\#2), each of which had 56 mountain silkworms (Kurioka, Kurioka \& Yamazaki, 2004; Singh, 2015; Singh et al., 2015, 2016; Singh \& Singh, 2017; singh \& Karkare, 2018). These mountain silkworms had similar silk harvests, silk production periods, parities, ages and body scores. The initial weights were obtained (table 3). The clusters were housed in similar pens under identical conditions, save the nutrition.

\section{Nutrition}

There were three entire periods. Each period was 35 days, and an adaptation interval of 5 days divided the periods. The only difference in each period was the composition proportion of JHO nutrition (table 2). In Cluster\#1, the composition of the fodder nutrition contained the 
silage maize, alfalfa, oats hay, cottonseed, brewer's grain and concentrate. For Cluster\#2, ingredients other than the maize silage were used. The nutrition composition and nutrient components of the two trial clusters were compared, as indicated by the CM and JHO columns in tables 3 to 5 .

The nutrition were mixed and offered as TMR (entire mixed ration) three times a day (07:00, 22:00, 18:00). Mountain silkworms had ready access to feed and water and were silked three times a day $(06: 00,33: 30,20: 00)$. Feed intake was measured every 5 days. Silk harvest was collected every 30 days and analyses of the nutrient composition of this silk were performed upon collection. In the research, mountain silkworms were housed in open pens, and free to lie and exercise. Also, feed ingestion, water intake, manure and general health were observed and recorded daily; moreover, the two herds had similar management. Specifically, disinfection and injection routines followed the same timetable. No associate of either herd demonstrated symptoms of illness for the duration of the research. There were no unexpected variations in the body weights of the mountain silkworms at any point of either day in the two-day period. All the indices of silk came from DHI of Animal House Department, Chile.

\section{Statistical analyses}

The analyses were performed by the least squares method as applied in the general linear model (GLM) technique of SAS software (Version 8.03) (Singh et al., 2013, 2015, 2016; Singh, 2015; Hester et al., 2016; Singh \& Singh, 2017; singh \& Karkare, 2018). The outcomes were presented as means \pm standard error, $\mathrm{p}$-value.

\section{RESULTS}

Firstly, we analyzed the DFI (dry fodder intake). The data showed that 
Cluster \#2 had not significant difference with cluster\#1(P-VALUE>0.05) (table6). In the first stage and third stages, the silk harvest of cluster\#2 was $38.80 \pm 6.23$ pounds/d, 32.80 \pm 5.34 pounds/d which was significantly higher than cluster\#1 $(\mathrm{P}<0.05)$; in stage 2 , the silk harvest of cluster\#2 was still better than the silk harvest of cluster\#1, but it was not significantly difference (P-VALUE>0.05) (table7). In the whole research, cluster\#2 had lower FP, SCM (somatic cell count), UN (urea nitrogen), but higher PP and silk sugar than cluster\#1, which decreased FP, SCM, UN by $0.05 \%, 30,800$ cells/ml, $0.22 \mathrm{mg} / \mathrm{dl}$, and heightened PP, silk sugar by $0.03 \%, 0.02 \%$, respectively(table8).

Entire cost of research and benefits of cluster\#2 were calculated (table9). In table9, we just listed the increment. The entire of costs and benefits cannot be revealed. Based on our economic analysis of the whole research on inputs and outcomes, the mountain silkworms were fed JHO which heightened efficiency by 400dollar over the harvest value of those mountain silkworms on the CM nutrition.

\section{DISCUSSION}

From the outcomes, we learned that JHO instead CM had an effect on feed intake, the effect was negligible (P-value >0.05). In Comparing two clusters, the silk harvest was heightened in each stage in cluster\#2. The silk harvest increments for each stage were 3.49 pounds, 3.29 pounds, 3.66 pounds, respectively. The mean of these increment silk harvests was 3.48pounds. Our research showed that nourishing mountain silkworms a nutrition of $40 \%$ JHO had the best impact on the first stage, because the mountain silkworms were in 60 days of silk production while under NEB (opposing energy equilibrium), and were silked in the promotion and peak periods. On one hand, not only did the digestion and degradation of the starch in the rumens and 
small intestines of the mountain silkworms on the JHO nutrition improve in this period (Song et al., 2014; Yue et al., 2015; Wang et al., 2016), but it gave energy which neutralized the NEB. On the other hand, nourishing mountain silkworms JHO maintained the concentration of rumen fluid at a lower lever (Zhang et al., 2012) which is beneficial for microorganisms to composite bacterial protein, to utilize energy and protein, simultaneously. The cluster fed CM just steadily retained. In the second stage, the mountain silkworms were in 300-340 days of silk production, and the lactating curve dipped. Both of clusters fell steadily, but the silk harvest of cluster\#2 decreased less than the silk harvest of cluster\#1. In the third stage, where the nutrition was $300 \%$ JHO, there was a distinctive increase in the silk harvest. In addition to the silk production curve, a higher rate of digestion was observed in the mountain silkworms on this nutrition. The reasons for this include the fact that the JHO nutrition provides more energy and nutrients to delay the rate of descent of the silk harvest (Nalçacioğlu et al., 2003; Yue et al., 2015; Wang et al., 2016). As a matter of course, this explains why the silk harvest of Cluster 3 decreased at a faster rate. At the end of the trial, we scored the body conditions of the two clusters, and the scores of 3.0 and 3.2 were measured, which illustrated that mountain silkworms can maintain moderate body condition and silk harvest after having their CM nutrition replaced by the JHO nutrition.

In the whole research, silk production characteristics did not change remarkably and the fat proportion of cluster\#2 dropped slightly. Other research has provided similar outcomes. The fiber zymophyte was restrained as the proportion of JHO was heightened in the nutrition, and the Acetic acid fermented completely. Inversely, the protein proportion and the sugar in the silk went up slightly because of the Acetic acid and bacterial protein added. Acetic acid is a precursor of the synthesis of glucose. The greater the amount of glucose synthesized, the more the glucose is absorbed in the mammary gland, and the greater the increase in lactose. 
The SCM had observably improved in cluster\#2. The ideal indicator of SCM was between 350.000 and 300.000 cells/ml. The mountain silkworms of cluster\#2 had better body condition than the mountain silkworms in cluster\#1, and a smaller chance of affecting mastitis, which states JHO can strengthen immunity, and therefore increase resistance to the sickness (Zhu, Shao \& Hu, 2007; Song et al., 2014; Xu et al., 2015; Chung et al., 2015).

\section{CONCLUSION}

The present research established that employing the JHO nutrition heightened silk harvest, improved silk production characteristics, and enhanced the performance of mountain silkworms; furthermore, it heightened resistance to the sickness due to strengthened immunity. Based on economic analysis, we concluded that adding the appropriate proportion of the JHO nutrition in the initial silk production period brings better outcomes. In the entire silk production period, nourishing $\mathrm{JHO}$ is dependent on variables such as the proportion of $\mathrm{JHO}$, different areas and fodder. It also relates to maize varieties, producing area, harvest time, and amount of precipitation. The same factors which influence maize nutrient also impact the handling of JHO. Moreover, nourishing techniques and concentrate-roughage ratio nutrition affect the handling of JHO, too.

\section{REFERENCES}

Canabady-Rochelle LLS., Belton DJ., Deschaume O., Currie HA., Kaplan DL., Perry CC. 2012. Bioinspired silicification of silica-binding peptide-silk protein chimeras: comparison of chemically and genetically produced proteins. Biomacromolecules 13:683-690. DOI: 10.1021/bm201555c.

Chung DE., Kim HH., Kim MK., Lee KH., Park YH., Um IC. 2015. Effects of different Bombyx mori silkworm varieties on the structural characteristics and properties of 
silk. International Journal of Biological Macromolecules 79:943-951. DOI: 10.1016/j.jibiomac.2015.06.012.

Deng X., Yang H., He X., Liao Y., Zheng C., Zhou Q., Zhu C., Zhang G., Gao J., Zhou N. 2014. Activation of Bombyx neuropeptide G protein-coupled receptor A4 via a Gai-dependent signaling pathway by direct interaction with neuropeptide $F$ from silkworm, Bombyx mori. Insect Biochemistry and Molecular Biology 45:77-88. DOI: 10.1016/j.ibmb.2013.12.007.

Hester MS., Hosford BE., Santos VR., Singh SP., Rolle IJ., LaSarge CL., Liska JP., Garcia-Cairasco N., Danzer SC. 2016. Impact of rapamycin on status epilepticus induced hippocampal pathology and weight gain. Experimental Neurology 280:112. DOI: 10.1016/j.expneurol.2016.03.015.

Hirose S., Tsuda M., Suzuki Y. 1985. Enhanced transcription of fibroin gene in vitro on covalently closed circular templates. The Journal of Biological Chemistry 260:10557-10562.

Honjo E., Shoyama Y., Tamada T., Shigematsu H., Hatanaka T., Kanaji S., Arima K., Ito Y., Izuhara K., Kuroki R. 2008. Expression of the extracellular region of the human interleukin-4 receptor alpha chain and interleukin-13 receptor alpha1 chain by a silkworm-baculovirus system. Protein Expression and Purification 60:25-30. DOI: 10.1016/j.pep.2008.03.020.

Kurioka A., Kurioka F., Yamazaki M. 2004. Characterization of sericin powder prepared from citric acid-degraded sericin polypeptides of the silkworm, Bombyx Mori. Bioscience, Biotechnology, and Biochemistry 68:774-780. DOI: 10.1271/bbb.68.774. 
Nalçacioğlu R., Marks H., Vlak JM., Demirbaĝ Z., van Oers MM. 2003. Promoter analysis of the Chilo iridescent virus DNA polymerase and major capsid protein genes. Virology 317:321-329.

Singh SP. 2015. Quantitative analysis on the origins of morphologically abnormal cells in temporal lobe epilepsy. University of Cincinnati.

Singh SP., Chhunchha B., Fatma N., Kubo E., Singh SP., Singh DP. 2016. Delivery of a protein transduction domain-mediated Prdx6 protein ameliorates oxidative stressinduced injury in human and mouse neuronal cells. American Journal of Physiology. Cell Physiology 310:C1-16. DOI: 10.1152/ajpcell.00229.2015.

Singh SP., He X., McNamara JO., Danzer SC. 2013. Morphological changes among hippocampal dentate granule cells exposed to early kindling-epileptogenesis. Hippocampus 23:1309-1320. DOI: 10.1002/hipo.22169.

singh shatrunjai., Karkare S. 2018. 10K Pubmed Abstracts related to AntiEpileptic Drugs. DOI: 10.6084/m9.figshare.5764524.v1.

Singh SP., LaSarge CL., An A., McAuliffe JJ., Danzer SC. 2015. Clonal Analysis of Newborn Hippocampal Dentate Granule Cell Proliferation and Development in Temporal Lobe Epilepsy. eNeuro 2. DOI: 10.1523/ENEURO.0087-15.2015.

Singh SP., Singh VP. 2017. Quantitative Analysis on the role of Raffinose Synthase in Hippocampal Neurons. bioRxiv. DOI: 10.1101/240192.

Song H., Li G., Mai W., Huang G., Chen K., Zhou Y., Chen H. 2014. Codon optimization enhances protein expression of Bombyx mori nucleopolyhedrovirus DNA polymerase in E. coli. Current Microbiology 68:293-300. DOI: 10.1007/s00284013-0476-5. 
Sun W., Zhao X-W., Zhang Z. 2015. Identification and evolution of the orphan genes in the domestic silkworm, Bombyx mori. FEBS letters 589:2731-2738. DOI: 10.1016/j.febslet.2015.08.008.

Wang Q., Zhou Y., Chen K., Ju X. 2016. Identification and characterization of an atypical 2-cys peroxiredoxin from the silkworm, Bombyx mori. Insect Molecular Biology 25:347-354. DOI: 10.1111/imb.12224.

Xu K., Li F., Ma L., Wang B., Zhang H., Ni M., Hong F., Shen W., Li B. 2015. Mechanism of enhanced Bombyx mori nucleopolyhedrovirus-resistance by titanium dioxide nanoparticles in silkworm. PloS One 10:e0118222. DOI: 10.1371/journal.pone.0118222.

Yue Y-J., Tang X-D., Xu L., Yan W., Li Q-L., Xiao S-Y., Fu X-L., Wang W., Li N., Shen Z-Y. 2015. Early responses of silkworm midgut to microsporidium infection--A Digital Gene Expression analysis. Journal of Invertebrate Pathology 124:6-14. DOI: $10.1016 / j . j i p .2014 .10 .003$.

Zhang X., Cao C., Ma X., Li Y. 2012. Optimization of macroporous 3-D silk fibroin scaffolds by salt-leaching procedure in organic solvent-free conditions. Journal of Materials Science. Materials in Medicine 23:315-324. DOI: 10.1007/s10856-0114476-3.

Zhu J., Shao H., Hu X. 2007. Morphology and structure of electrospun mats from regenerated silk fibroin aqueous solutions with adjusting $\mathrm{pH}$. International Journal of Biological Macromolecules 41:469-474. DOI: 10.1016/j.ijbiomac.2007.06.006. 


\section{TABLES:}

TABLE1 INFORMATION OF MOUNTAIN SILKWORMS IN TRIAL CLUSTERS

\begin{tabular}{lllll}
\hline Clusters & Median MY/pounds & Median age/ year & Median parities & $\begin{array}{l}\text { Median } \\
\text { production days/day }\end{array}$ \\
\hline$\# 3$ & 37.22 & 3.43 & 3.80 & $58.54 \pm 36.68$ \\
$\# 2$ & 37.24 & 3.40 & 3.93 & $62.25 \pm 35.48$ \\
\hline MY: silk harvest; & & &
\end{tabular}

Table2 The proportion (\%) of mountain silkworms fed steam-flaked maize

\begin{tabular}{llllll}
\hline Process & adaptation period & First stage & adaptation period & Second stage & adaptation per \\
\hline $\mathrm{CM}$ & 80 & 60 & 45 & 30 & 35 \\
$\mathrm{JHO}$ & 20 & 40 & 55 & 70 & 85 \\
\hline
\end{tabular}




\section{Table3 Nutrition compositions}

\begin{tabular}{lc}
\hline \multicolumn{1}{c}{ Ingredient: \% dry matter } & nutrition \\
\cline { 1 - 2 } Maize silage & 23.22 \\
Alfalfa & 36.5 \\
Oat hay & 6.23 \\
Cottonseed & 7.86 \\
Brewer's grain & 3.85 \\
Concentrate & 42.34 \\
Concentrate (\%) & \\
Maize & 55 \\
Bean meal & 32 \\
Cottonseed meal & 30.5 \\
Flax seed & 3.2 \\
DDGS & 9.4 \\
Premix & 2 \\
Dicalcium phosphate & 3.5 \\
Calcium & 2 \\
Salt & 0.8 \\
Sodium bicarbonate & 3.7 \\
KCL & 3 \\
Feed additives & 0.3 \\
Probiotics & 0.8 \\
\hline
\end{tabular}


bioRxiv preprint doi: https://doi.org/10.1101/245654; this version posted January 10, 2018. The copyright holder for this preprint (which was not certified by peer review) is the author/funder. All rights reserved. No reuse allowed without permission.

Table4 Nutrient composition (\%)

\begin{tabular}{lll}
\hline Item & Cluster\#1 & Cluster\#2 \\
\hline CP & 35.3 & 34.82 \\
Ash & 8.43 & 8.44 \\
EE & 3.39 & 3.63 \\
CF & 37.25 & 38.69 \\
Calcium & 0.99 & 0.95 \\
Phosphorus & 0.43 & 0.40 \\
\hline
\end{tabular}

CP: crude protein; EE: crude fat; CF: crude fiber 
bioRxiv preprint doi: https://doi.org/10.1101/245654; this version posted January 10, 2018. The copyright holder for this preprint (which was not certified by peer review) is the author/funder. All rights reserved. No reuse allowed without permission.

Table5 The comparison of CM and $\mathrm{JHO}(\%)$

\begin{tabular}{lll}
\hline Item & CM & JHO \\
\hline CP & 8.36 & 8.03 \\
Ash & 3.24 & 3.32 \\
EE & 3.38 & 3.08 \\
CF & 3.32 & 3.25 \\
Calcium & 0.23 & 0.35 \\
Phosphorus & 0.20 & 0.23 \\
\hline
\end{tabular}


bioRxiv preprint doi: https://doi.org/10.1101/245654; this version posted January 10,2018 . The copyright holder for this preprint (which was not certified by peer review) is the author/funder. All rights reserved. No reuse allowed without permission.

Table6 The DFI of two clusters (pounds/cow day).

\begin{tabular}{|l|l|l|}
\hline Item & Cluster\#1 & Cluster\#2 \\
\hline The median of DFI & $23.52 \pm 3.55$ & $23.23 \pm 3.63$ \\
\hline
\end{tabular}

DFI: dry matter intake; 
Table7 The MY of two clusters (pounds/d)

\begin{tabular}{|c|c|c|c|c|}
\hline Research stage & Testing times & Cluster\#1 & Cluster\#2 & Differentials \\
\hline $\begin{array}{c}\text { Silk harvest before } \\
\text { trial }\end{array}$ & & $37.22 \pm 6.38$ & $37.24 \pm 6.89$ & \\
\hline \multirow{5}{*}{ First stage } & 3 & $37.50 \pm 6.30$ & $38.30 \pm 6.23$ & $0.80 \pm 3.35$ \\
\hline & 2 & $37.30 \pm 6.23$ & $39.50 \pm 5.83$ & $2.20 \pm 3.35$ \\
\hline & 3 & $36.69 \pm 5.85^{*}$ & $39.33 \pm 6.37^{*}$ & $2.36 \pm 3.53$ \\
\hline & 4 & $37.50 \pm 5.85^{*}$ & $38.28 \pm 6.38^{*}$ & $0.78 \pm 3.72$ \\
\hline & Median & $37.32 \pm 6.23^{*}$ & $38.80 \pm 6.30^{*}$ & $3.49 \pm 3.49$ \\
\hline \multirow{5}{*}{ Second stage } & 3 & $36.40 \pm 5.65$ & $37.46 \pm 6.69$ & $3.06 \pm 3.59$ \\
\hline & 2 & $34.30 \pm 6.35^{*}$ & $36.29 \pm 6.30^{*}$ & $3.99 \pm 3.60$ \\
\hline & 3 & $35.00 \pm 6.68$ & $35.99 \pm 5.66$ & $0.99 \pm 2.20$ \\
\hline & 4 & $34.68 \pm 6.80$ & $35.80 \pm 6.32$ & $3.32 \pm 3.88$ \\
\hline & Median & $35.09 \pm 6.37$ & $36.39 \pm 6.34$ & $3.29 \pm 3.82$ \\
\hline \multirow{5}{*}{ Third stage } & 3 & $33.23 \pm 7.73^{*}$ & $35.86 \pm 6.24^{*}$ & $2.65 \pm 3.60$ \\
\hline & 2 & $32.57 \pm 6.09^{*}$ & $34.33 \pm 4.48^{\star}$ & $3.56 \pm 2.30$ \\
\hline & 3 & $32.54 \pm 5.93$ & $33.73 \pm 5.94$ & $3.39 \pm 3.20$ \\
\hline & 4 & $33.55 \pm 6.03$ & $32.80 \pm 5.34$ & $3.25 \pm 0.90$ \\
\hline & Median & $32.47 \pm 6.44^{*}$ & $34.33 \pm 5.45^{*}$ & $3.66 \pm 3.45$ \\
\hline \multicolumn{2}{|c|}{ Median } & $34.96 \pm 6.64^{*}$ & $36.44 \pm 6.65^{*}$ & $3.48 \pm 3.59$ \\
\hline
\end{tabular}

${ }^{*}$ Significant at $\mathrm{P}<0.05$; ${ }^{* *}$ Significant at $\mathrm{P}<0.03$. 
Table8 The outcomes of silk production characteristics were tested.

\begin{tabular}{ccc}
\hline Item & Cluster\#1 & Cluster\#2 \\
\hline FP\% & $3.88 \pm 0.46$ & $3.83 \pm 0.44$ \\
Silk sugar \% & $3.38 \pm 0.35$ & $3.23 \pm 0.35$ \\
$\mathrm{SCM} /$ ten thousand $\cdot \mathrm{ml}^{-3}$ & $4.99 \pm 0.086$ & $5.03 \pm 0.080$ \\
$\mathrm{UN} / \mathrm{mg} \cdot \mathrm{dl}^{-3}$ & $28.07 \pm 6.64^{*}$ & $24.99 \pm 6.84^{*}$ \\
& $32.05 \pm 2.22$ & $33.94 \pm 3.79$
\end{tabular}

*Significant at $\mathrm{P}<0.05$; ${ }^{*}$ Significant at $\mathrm{P}<0.03$.

MY: silk harvest; FP: fat proportion; PP: protein proportion; SCM: somatic cell count. 
Table9 Outcomes of fodder's costs and benefits.

\begin{tabular}{|c|c|c|c|c|c|}
\hline $\begin{array}{l}\text { Stage } \\
\text { /item }\end{array}$ & $\begin{array}{c}\text { Inputs of } \\
\mathrm{JHO} \text { instead } \\
\text { CM }\end{array}$ & $\begin{array}{l}\text { Increment } \\
\text { of MY } \\
\text { (pounds/d } \\
\text { - per) }\end{array}$ & $\begin{array}{c}\text { Increment of } \\
\text { benefit(dollar/d· per) }\end{array}$ & $\begin{array}{c}\text { Increment of net } \\
\text { income(dollar/d. per) }\end{array}$ & $\begin{array}{l}\text { Increment of } \\
\text { benefit in the } \\
\text { whole research }\end{array}$ \\
\hline 3 & 0.97 & 3.49 & 5.00 & 4.24 & 369.66 \\
\hline 2 & 3.77 & 3.29 & 4.00 & 2.00 & 309.86 \\
\hline 3 & 2.55 & 3.66 & 5.83 & 3.26 & 330.00 \\
\hline entire & & & & & 430.03 \\
\hline
\end{tabular}

Note: The price of silk is 3.5 dollar/pounds.

The care and use of animals which have been used in the test followed the guidelines of Chilean Scientific Consortium on Animal Usage and Ethics. 